\title{
Improving Corn Cobs Utilization In Sheep Ration Using Biological Treatment
}

\author{
Salama, R' ${ }_{\text {; }}$ R.I. El-Kady ${ }^{2}$; M.I. Mohamed ${ }^{2}$; M.A. Boraie ${ }^{1}$ and S.A.E.Abd-Allah $^{2}$
}

1- Animal Production Department, Faculty of Agriculture, Al-Azhar University, Nasr City, Cairo, Egypt

2- Department of Animal Production, National Research Center, Dokki, Giza, Egypt.

\begin{abstract}
The main objectives of the present experiment were to investigate the effect of biological treatment (fungus + yeast) on chemical composition and utilizability of treated (corn cobs) in sheep ration. Twenty growing cross bred (Rahmani $\times$ Ossimi) male lambs of 4 months old and mean body weight $28 \mathrm{~kg}$ were distributed into four similar groups. The treated corn cobs were to replace $0,10,20$ or $30 \%$ of Berseem hay included in the feed mixture fed to growing lamb groups $R_{1}$, $R_{2}, R_{3}$ and $R_{4}$, respectively. The experimental period lasted for 90 days. Feed mixtures were offered daily at $3 \%$ of live body weight and groundnut vines were ad-lib.Results indicated that, the average body weight gain, feed intake and feed efficiency differed significantly higher for sheep fed $R_{4}$ followed by $R_{3}$. However, no significant differences were detected between $R_{2}$ and the control ration. Feed efficiency values were significantly between groups and the highest values were recorded with $\mathrm{R}_{4}$ and $\mathrm{R}_{3}$. Digestibilities of $\mathrm{DM}, \mathrm{OM}, \mathrm{CP}$ and $\mathrm{EE}$ were significantly different among groups. The highest values were recorded for $\mathrm{R}_{4}$ ration of almost nutrients. Concentration of ammonia-nitrogen $\left(\mathrm{NH}_{3}-\mathrm{N}\right)$ and total volatile fatty acids at $3 \mathrm{hrs}$ post feeding were significantly higher in treated groups than that of control one. However, the least feed cost $/ \mathrm{kg}$ gain was that of treatment (R4) followed by (R3) than the control.
\end{abstract}


The biological treatments applied in the present study could be used without any adverse effect on the tested hemato-biochemical parameters. It could be concluded that replacement up to $30 \%$ of Berseem hay by biological treated corn cobs improved the productive performance of growing lambs.

Key words: Biological treatments, Sheep, Digestibility, Rumen liquor parameters, Blood parameters.

\section{INTRODUCTION}

There is an urgent need to search for more available and cheaper roughage, particularly agricultural by-products as corn cobs for animal feeding, because there is a gap between animal requirements and the available animal's feed, so biological treatments are preferable than other treatments such chemical treatment for better and clear environment. Residues are burned or wasted and hence lead to environmental pollution and consequently health hazards. The primary factors limiting the utilization of crop residues are low digestibility, low protein content and low platability. Biological treatments such as Trichoderma viride (Shoukry,et al., 1985., Khorshed,2000 and El-Ashry et al., 2003) were used to improve the nutritive value and digestibility of poor quality roughages. Increasing the digestibility of the diet by using exogenous feed enzymes obtained from fungal treatment will be lead to the beneficial effects on animal performance, also yeast treatment was used to improve rumen digestibility of nutrients especially crude fiber, elevation rumen fermentation and more activation of rumen microorganisms (Dawson, 1992).

This study aimed to investigate the ability of biological treatment (fungi and yeast) to improve nutritive value as total digestible nutrient (TDN) and digestible crude protein (DCP) of corn cobs as crop residues 
and the effect of biological treatments of corn cobs on nutrient digestibility, rumen fermentation and economical study on growing sheep ration.

\section{MATERIALS AND METHODS}

This study was carried out at Sheep and Goat Research Unit that belong to Animal Production Department at National Research Center, Dokki, Giza. Trichoderma reesei F-418 and Saccharomyces cervisiae AFZ-98 were obtained from Microbial Chemistry Department, National Research Centre, Dokki, Egypt.

\section{Biological treatment:}

Trichoderma reesei F-418 and Saccharomyces cervisiae AFZ-98 were propagated for biological treatment according to the method described by Fadel (2001). The crushed corn cobs (150 kg) were moistened by a medium containing urea $2 \%$, ammonium sulphate $1.0 \%$, magnesium sulphate $0.5 \%$, tricalcium phosphate $1.0 \%$ and molasses $2 \%$ at a ratio of solid: liquid (1:2), then inoculated by prepared fungal inoculum at $10 \%(\mathrm{w} / \mathrm{w})$. Yeast inoculum at $1 \%(\mathrm{w} / \mathrm{w})$ was added after $(48$ hrs) from fermentation being the treatment was continued for ten days. At the end of fermentation period, the tested materials were manual mixing at intervals (48 hrs) and exposed to sun dry until the moisture content reached less than $10 \%$, then stored until be used.

Composting producers and combined fungal and yeast treatment of corn cobs:

One ton from the previous crushed corn cobs mention before was moistened with a medium contained $25 \mathrm{~kg}$ molasses, $15 \mathrm{~kg}$ urea of $46.5 \% \mathrm{~N} 10 \mathrm{~kg}$ super phosphate, $20 \mathrm{~kg}$ ammonium sulphate $20.6 \% \mathrm{~N}$ and 5 $\mathrm{Kg}$ magnesium sulphate at solid: liquid ratio (1: 2). The inoculum of 
fermented fungal biomass and growing yeast culture were used at $0.1 \%$ (w/w), mixed well and spread on plastic sheet $(2 \times 5 \mathrm{~m})$, corn cobs treated were shuffled up side down daily for 10 days. At the end of the fermentation period, the treated corn cobs were collected and exposed to sun dry until the moisture content reached less than $10 \%$ then packed and stored until be used.

\section{Manufacturing the pelleted rations and animal feeding:}

The air dried corn cobs have been transported to the manufacture for making the experimental pelleted feed. All ingredients of each ration were mixed well. Substitution of Berseem hay with biologically treated corn cobs (T.C.C.) with mixture of fungi and yeast (50\% of each) at a rate of $10 \%$, $20 \%$ and $30 \%$ (complete substitution) of Berseem hay with treated corn cobs.

Formulation and chemical composition of the experimental rations as follows:

1) The $1^{\text {st }}$ mixture contained ( $0 \%$ corn cobs biologically treated $+30 \%$ Berseem hay). ( $R_{1}$ ).

2) The $2^{\text {nd }}$ mixture contained $(10 \%$ corn cobs biologically treated $+20 \%$ Berseem hay ). ( $\left.\mathrm{R}_{2}\right)$.

3) The $3^{\text {rd }}$ mixture contained $(20 \%$ corn cobs biologically treated $+10 \%$ Berseem hay). $\left(\mathrm{R}_{3}\right)$.

4) The $4^{\text {th }}$ mixture contained ( $30 \%$ corn cobs biologically treated $+0 \%$ Berseem hay).( $\left.\mathrm{R}_{4}\right)$

All rations were nearly isocaloric and isonitrogenous. Formulation and chemical composition of the experimental concentrate feed mixture, treated corn cobs and groundnut vines are presented in Tables (1 and 2). 
In this regard, twenty growing crossbred (Rahmani $\times$ Ossimi) male lambs 4 months old (averaged $28.0 \mathrm{~kg}$ ) were divided into 4 similar groups (each group of 5 lambs). The growth trials lasted for 90 days, each group was kept in a separate shaded pen and randomly offered tested rations. The experimental feed mixtures were offered at 3\% of live body weight and groundnut vines were offered $a d-l i b$. Feed was group feeding two times daily at 8 a.m. and at 5 p.m., while feed residues were removed and weighed once daily before morning feeding to estimate daily feed intake. Fresh water and mineral blocks were freely available all times. Lamb weights were recorded at the beginning of the experiment and thereafter at biweekly intervals till the end of the experiment. Feeding rations of the experimental lambs were changed every 2 weeks according to body weight changes.

At the end of the experiment, four digestibility trials were carried out by using 3 animals, chosen randomly from each experimental group to determine nutrients digestibility and nutritive values of the experimental rations. Animals were kept in metabolic cages for 14 days before sample collection. Feces were collected daily during the collection period extended for 5 days, weighed and representative samples $(10 \%$ of weight) were taken. Animals were fed their rations as described above and the residual was collected and weighted daily. Animals were allowed free access to water.

\section{Rumen liquor :}

Rumen liquor samples were collected at 0,3 and 6 hours after the morning feeding from 3 lambs of each group during the feeding trial using stomach tube. Samples were filtered through a double layer of cheesecloth. Ruminal $\mathrm{pH}$ value was immediately estimated using Orion 680 digital $\mathrm{pH}$ meter. Few drops of a saturated solution of mercuric 
chloride were used to stop microbial activity and the samples were stored in polyethylene bottles in a freezer until analysis. Concentration of TVFA's was determined using steam distillation method (Warner, 1964). The concentration of ammonia- $\mathrm{N}$, feed and feces were analyzed according to AOAC (1995) methods. Data were subjected to statistical analysis using SAS (1989) with one way ANOVA while differences among means were tested using L S D (Duncan, 1955).

\section{Blood profile:}

Blood samples were collected from the jugular vein before feeding (0 time) from five lambs of each group once at end of the experiment. Whole blood was immediately used for hematological estimations. Another blood sample was directly collected into a clean dried tube and centrifuged at 4000 r.p.m. for 20 min. then the blood serum was separated into a clean dried glass vial and stored at $-18^{\circ} \mathrm{C}$ to determine serum total protein (Armestrong and Carr, 1964), albumin (Doumas et al., 1971), AST and ALT (Reitman and Frankel, 1957), urea (Patton and Crouch, 1977), creatinine (Husdan, 1968), glucose (Siest et al., 1981), total lipids (Postma and Stroes, 1968) and cholesterol (Raltiff and Hall, 1973). globulin and albumin/globulin ratio were calculated.

\section{Feed conversion and economic efficiencies:}

Feed conversion was calculated as the amount of DM and TDN $(\mathrm{Kg})$ required per $\mathrm{Kg}$ live body weight gain. Economic efficiency expressed as the daily feed cost, price of daily weight gain, feed cost per $\mathrm{Kg}$ gain and the ratio between daily feed cost and price of daily weight gain. The prices in Egyptian pounds (LE/ton) were 200 Corn Cobs, 700 Berseem hay and 17 for one kg live weight gain. 


\section{Results and Discussion}

The composition of different experimental rations are presented in table (1), while the chemical composition of the experimental rations are presented in table (2). The data showed nearly isocaloric and isonitrogenous for different experimental rations.

Table (1): Composition for experimental rations (Kg/100Kg).

\begin{tabular}{|l|c|c|c|c|}
\hline \multirow{2}{*}{ Ingredient } & \multicolumn{4}{|c|}{ Experimental rations } \\
\cline { 2 - 5 } & $\begin{array}{c}\mathbf{0 \%} \text { T.C.C. } \\
\left(\mathbf{R}_{\mathbf{1}}\right)\end{array}$ & $\begin{array}{c}\mathbf{1 0 \%} \text { T.C.C. } \\
\left(\mathbf{R}_{2}\right)\end{array}$ & $\begin{array}{c}\mathbf{2 0 \%} \text { T.C.C. } \\
\left(\mathbf{R}_{3}\right)\end{array}$ & $\begin{array}{c}\mathbf{3 0 \%} \text { T.C.C.* } \\
\left(\mathbf{R}_{\mathbf{4}}\right)\end{array}$ \\
\hline Yellow corn & 35.0 & 35.0 & 35.0 & 35.0 \\
\hline Treated corn cobs & -- & 10 & 20 & 30 \\
\hline Berseem hay & 30 & 20 & 10 & -- \\
\hline Undecorticatd cottonseed meal & 10 & 10 & 10 & 10 \\
\hline Soybean meal (44\%) & 8 & 8 & 8 & 8 \\
\hline Wheat bran & 10 & 10 & 10 & 10 \\
\hline Molasses & 4 & 4 & 4 & 4 \\
\hline Calcium carbonate & 1.8 & 1.8 & 1.8 & 1.8 \\
\hline Sodium chloride (NaCl) & 1.0 & 1.0 & 1.0 & 1.0 \\
\hline Minerals and vitamins & 0.2 & 0.2 & 0.2 & 0.2 \\
\hline
\end{tabular}

* T.C.C : Biological treated corn cobs.

Table (2): Chemical composition of concentrate feed mixture, treated corn cobs and groundnut vines.

\begin{tabular}{|l|c|c|c|c|c|c|c|}
\hline \multirow{2}{*}{\multicolumn{1}{|c|}{ Item }} & \multirow{2}{*}{ DM } & \multicolumn{6}{|c|}{ Chemical composition \% on DM basis } \\
\cline { 3 - 8 } & & OM & CP & CF & EE & NFE & Ash \\
\hline 0\% T.C.C. $\left(\mathrm{R}_{1}\right)$ & 90.84 & 94.52 & 14.07 & 14.20 & 3.39 & 62.86 & 5.48 \\
\hline 10\% T.C.C. $\left(\mathrm{R}_{2}\right)$ & 91.30 & 94.67 & 14.50 & 14.42 & 3.26 & 62.49 & 5.33 \\
\hline 20\% T.C.C. $\left(\mathrm{R}_{3}\right)$ & 91.22 & 94.59 & 14.30 & 14.55 & 3.08 & 62.66 & 5.41 \\
\hline 30\% T.C.C. $\left(\mathrm{R}_{4}\right)$ & 91.13 & 95.90 & 14.35 & 14.90 & 2.93 & 63.72 & 4.10 \\
\hline Treated corn cobs & 90.53 & 94.77 & 14.82 & 31.43 & 1.03 & 47.49 & 5.23 \\
\hline Groundnut vines hay & 88.43 & 87.35 & 10.09 & 30.12 & 2.79 & 44.35 & 12.65 \\
\hline
\end{tabular}




\section{Growth performance:}

The average body weight gain, feed intake and feed conversion are given in Table (3). Average daily weight gain was significantly higher for sheep fed $\mathrm{R}_{4}$ followed by $\mathrm{R}_{3}$ ration. However, no significant difference was detected between $R_{2}$ and the control one in daily weight gain. Data showed that inclusion treated corn cobs up to $(30 \%)$ in $\mathrm{R}_{4}$ ration recorded the highest average daily weight gain followed by $\mathrm{R}_{3}$. However, $\mathrm{R}_{2}(10 \%$ treated corn cobs) did not increase the beneficial effects of the fungal +yeast preparation used in daily body weight gain. Similar results were reported by Deraz (1996) and El-Kady et al. (2006).

Total dry matter intake (TDMI) slightly increased with $\mathrm{R}_{4}, \mathrm{R}_{3}$ and $\mathrm{R}_{2}$ compared to(control) $\mathrm{R}_{1}$. These results of DMI with fungal treatment agreed with those obtained by Beaychemin et al. (1999); Rode et al. (1999) and Yang et al. (1999). However Bouattour(2004), Flores (2004); Gonzilez (2004), Titi (2004); and El-Kady et al. (2006) reported that fungal or enzymatic treatments obtained from fungal did not alter dry matter intake. In contrast, others have reported increased feed intake (Lewis et al., 1999 and Mc Allister et al., 1999).Total digestible nutrients as TDN , $\mathrm{g}$ or TDN $\mathrm{Kg} \mathrm{w}^{0.75}$ and digestible crude protein (DCP) $\mathrm{g} / \mathrm{h} / \mathrm{d}$ or DCP $\mathrm{g} / \mathrm{Kg} \mathrm{w}^{0.75}$ were significantly higher for sheep fed $\mathrm{R}_{4}$ than other treatments.

Feed conversion as $\mathrm{Kg}$ dry mater intake/kg gain and as $\mathrm{kg} \mathrm{TDN} / \mathrm{Kg}$ gain were significantly differ among groups, and the best values were recorded with $R_{4}$ and $R_{3}$, while there was no significant difference in feed conversion between $R_{2}$ and the control rations. The improvement in TDN/gain of biologically treatment might due to the improvement of digestibility. Similar results were obtained by Plata-Perez 
et al., (2004); Titi (2004);Haddad and Goussous (2005) and ElKady et al., (2006) who found that exogenous fibrolylic enzymes obtained from Trichoderma viride resulted in improved $(\mathrm{P}<0.05)$ feed conversion ratio and daily gain of fattened Awassi lambs with no effect on feed intake. Results indicated that fibrolytic enzymes could enhance the growth of fattened lambs and improve their conversion ratios mainly through improving digestibility.

Table (3): Effect of the experimental rations on growth performance of growing lambs.

\begin{tabular}{|l|c|c|c|c|}
\hline \multicolumn{1}{|c|}{ Items } & $\mathbf{R}_{\mathbf{1}}$ & $\mathbf{R}_{\mathbf{2}}$ & $\mathbf{R}_{\mathbf{3}}$ & $\mathbf{R}_{\mathbf{4}}$ \\
\hline Initial live body weight (I.B.W.), Kg & 28 & 28 & 28 & 28 \\
\hline Final live body weight (F.B.W.), Kg & $49.6^{\mathrm{c}^{\mathrm{y}} \pm}$ & $49.8^{\mathrm{c}} \pm$ & $51.9^{\mathrm{b}} \pm$ & $52.8^{\mathrm{a}} \pm$ \\
& 0.859 & $0.973^{\mathrm{c}}$ & 1.138 & 0.937 \\
\hline Total body gain, Kg & $21.6^{\mathrm{c}} \pm$ & $21.8^{\mathrm{c}} \pm$ & $23.9^{\mathrm{b}} \pm$ & $24.8^{\mathrm{a}} \pm$ \\
& 1.167 & 1.189 & 1.393 & 2.053 \\
\hline Av. daily body gain, g & $240^{\mathrm{c}} \pm$ & $242^{\mathrm{c}} \pm$ & $266^{\mathrm{b}} \pm$ & $276^{\mathrm{a}} \pm$ \\
& 11.847 & 14.692 & 8.083 & 9.203 \\
\hline DM intake, g /h /d & & & & \\
Feed mixture & 1057 & 1065 & 1064 & 1066 \\
Roughage & 570 & 580 & 580 & 600 \\
Total dry matter intake (TDMI) g & 1627 & 1645 & 1644 & 1666 \\
\hline TDN, g / h /d & $1144.59^{\mathrm{b}}$ & $1159.72^{\mathrm{b}}$ & $1184.83^{\mathrm{b}}$ & $1244.17^{\mathrm{a}}$ \\
& \pm 0.610 & \pm 0.44 & \pm 0.350 & \pm 0.404 \\
\hline TDN kg w ${ }^{0-75}$ & $73.60^{\mathrm{b}} \pm$ & $74.48^{\mathrm{b}} \pm$ & $74.56^{\mathrm{b}} \pm$ & $77.66^{\mathrm{a}} \pm$ \\
& 0.450 & 0.379 & 0.430 & 0.404 \\
\hline Digestible crude protein (DCP) g/h/d & $145.13^{\mathrm{b}} \pm$ & $146.73^{\mathrm{b}}$ & $144.50^{\mathrm{b}}$ & $165.60^{\mathrm{a}}$ \\
& 0.233 & \pm 0.395 & \pm 0.067 & \pm 0.050 \\
\hline DCP, g/Kg w ${ }^{0-75}$ & $9.33^{\mathrm{b}} \pm$ & $9.42^{\mathrm{b}} \pm$ & $9.090^{\mathrm{b}} \pm$ & $10.33^{\mathrm{a}} \pm$ \\
\hline Feed conversion & 0.337 & 0.323 & 0.20 & 0.082 \\
\hline DMI Kg/Kg gain & $6.78^{\mathrm{a}} \pm$ & $6.79^{\mathrm{a}} \pm$ & $6.18^{\mathrm{b}} \pm$ & $6.04^{\mathrm{b}} \pm$ \\
\hline TDN intake kg/kg gain & 0.125 & 0.184 & 0.152 & 0.133 \\
\hline
\end{tabular}

$a, b$ and $c:$ Means within a row with different superscript are significantly different at $(\mathrm{P} \leq 0.05)$. 


\section{Digestion coefficient and nutritive values:}

Results of nutrient digestion coefficients and nutritive values of the experimental feed mixtures are shown in Table (4). Digestibilities of DM, $\mathrm{OM}, \mathrm{CP}$, and EE were significantly different among groups. The highest digestibility values were recorded for $\mathrm{R}_{4}$ ration of almost nutrients. However, the CP digestibility values were nearly similar and significantly higher with $R_{3}$ and $R_{4}$ rations in comparison with $R_{2}$ and the control rations. However, no significantly differences were obtained in NFE digestibility for all tested rations. The improvement in almost nutrient digestibility of biological treatment agreed with Ward and Perry (1982) when treated corn cobs with (Trichoderma viride). In addition, Rai and Mudgal (1984) found that the in-vitro digestibility of almost nutrients were higher $(\mathrm{P}<0.01)$ in wheat straw treated with cellulase (made from $T$. viride). However, El-Ashry et al. (1997) observed that both chemical or biochemical (urea + Penicillium funiculosum) treatment of the chopped roughage improved $(\mathrm{P}<0.05)$ ration digestibilities as $\mathrm{DM}, \mathrm{OM}, \mathrm{CP}$ and $\mathrm{CF}$ than the control ration, using Ossimi mature rams.

Moreover, Khorshed (2000) reported that all biological treatments (T. viride, S. cervisial or $T$. viride $+S$. cerevisiae) significantly increased apparent nutrient digestibilities for DM, OM, CP, CF and NFE. On the other hand, Zewil (2005) showed that almost nutrient digestibilities were improved with Trichoderma viride fungus treatment of sheep rations. Also, Gutierrez et al. (2005) reported that both amylolytic thermostable enzymes obtained from fungus treatment have the potential to become feed additives to improve ruminal digestibility of corn and sorghum, and are stable at low humidity conditions which may facilitate incorporation with grain during feed processing. Similar results were obtained also by El-Kady et al. (2006). 
It is worthy to note that the improving of digestibility of nutrients $\left(\mathrm{R}_{4}\right)$ led to improve the nutritive value of diets. So, the treatment of corn cobs with (Trichoderma reesi $+S$. cervisiae) with $\mathrm{R}_{4}$ group significantly improved the feeding values as TDN and DCP. Data showed that the dietary inclusion of treated corn cobs lower than (30\%) did not improved the nutritive value of sheep rations.

Table (4): Digestion coefficients and nutritive values of the experimental rations (on DM basis).

\begin{tabular}{|l|c|c|c|c|}
\hline \multirow{2}{*}{ Item } & \multicolumn{4}{c|}{ Experimental rations } \\
\cline { 2 - 5 } & $\mathbf{R}_{\mathbf{1}}$ & $\mathbf{R}_{\mathbf{2}}$ & $\mathbf{R}_{\mathbf{3}}$ & $\mathbf{R}_{4}$ \\
\hline No. of animal & 3 & 3 & 3 & 3 \\
\hline Mean live body weight & 53.66 & 55.33 & 53.30 & 53.60 \\
\hline Total DM intake, g/h/d & 1567.48 & 1611.32 & 1547.80 & 1596.00 \\
\hline Feed mixture g/h/d & 975.00 & 1010.00 & 973.00 & 977.00 \\
\hline Ground nut hay g/h/d & 592.48 & 601.32 & 574.80 & 619.00 \\
\hline DM intake \% of body weight & 2.92 & 2.91 & 2.90 & 2.97 \\
\hline Apparent digestibility(\%): & & & & \\
DM & $67.81^{\mathrm{b}} \pm$ & $66.05^{\mathrm{b}} \pm$ & $66.98^{\mathrm{b}} \pm$ & $70.71^{\mathrm{a}} \pm$ \\
& 1.173 & 0.945 & 0.618 & 0.453 \\
\hline OM & $71.44^{\mathrm{b}} \pm$ & $71.32^{\mathrm{b}} \pm$ & $72.17^{\mathrm{ab}} \pm$ & $75.43^{\mathrm{a}} \pm$ \\
& 0.661 & 0.713 & 0.546 & 0.667 \\
\hline CP & $63.43^{\mathrm{b}} \pm$ & $61.54^{\mathrm{b}} \pm$ & $68.97^{\mathrm{a}} \pm$ & $69.37^{\mathrm{a}} \pm$ \\
& 0.892 & 0.387 & 0.642 & 1.627 \\
\hline CF & $58.41^{\mathrm{b}} \pm$ & $58.80^{\mathrm{b}} \pm$ & $60.46^{\mathrm{b}} \pm$ & $66.69^{\mathrm{a}} \pm$ \\
& 0.963 & 0.874 & 0.288 & 0.895 \\
\hline \multirow{2}{*}{ EE } & $76.02^{\mathrm{b}} \pm$ & $77.52^{\mathrm{b}} \pm$ & $77.91^{\mathrm{b}} \pm$ & $80.02^{\mathrm{a}} \pm$ \\
& 0.405 & 0.455 & 0.453 & 0.486 \\
\hline NFE & $75.31 \pm$ & $75.88 \pm$ & $76.64 \pm$ & $77.45 \pm$ \\
\hline Nutritive value, \% & 0.732 & 0.354 & 0.379 & 0.332 \\
Total digestible nutrients (TDN) & & & & \\
& $70.35^{\mathrm{b}} \pm$ & $70.50^{\mathrm{b}} \pm$ & $72.07^{\mathrm{b}} \pm$ & $74.68^{\mathrm{a}} \pm$ \\
\hline \multirow{2}{*}{ Digestible crude protein (DCP) } & 0.617 & 0.452 & 0.379 & 0.435 \\
\hline
\end{tabular}

$\mathrm{a}$ and $\mathrm{b}$ : Means within a row with different superscript are significantly different at $(\mathrm{P} \leq 0.05)$. 


\section{Rumen liquor parameters:}

The results indicated that $\mathrm{pH}$ values were not affected by the treatments (Table 5). Similar results were obtained by El-Ashry et al.(1997) who found that biological treatments (fungi or enzymes) did not affect rumen $\mathrm{pH}$. Abd El-Kareem (1990) noticed that the ruminal $\mathrm{pH}$ values decreased gradually reaching the lowest values at $2 \mathrm{hrs}$ after feeding and tended to increase again after 4 and $6 \mathrm{hrs}$. Also Tawila (1991) found that the overall mean of $\mathrm{pH}$ in rumen liquor of sheep before morning feeding was found to be 7.1 then decreased to 6.4 at 2 and 4 hrs after feeding and tended to increase again after $6 \mathrm{hrs}$ to reach 6.7 .

Ammonia- $\mathrm{N}\left(\mathrm{NH}_{3}-\mathrm{N}\right)$ concentration reached the maximum after 3 hours of feeding in all groups. However, $\mathrm{NH}_{3}-\mathrm{N}$ concentrations were significantly higher $(\mathrm{P}<0.05)$ in the treated groups than the control group. After 6 hours of feeding, $\mathrm{NH}_{3}-\mathrm{N}$ concentration tended to decrease in all groups. This agrees with the results reported by Williams and Newbold (1990). They reported that the reduction of ammonia- $\mathrm{N}$ in the rumen liquor appears to be the result of increased incorporation of ammonia- $\mathrm{N}$ into microbial protein and it was considered as a direct result to stimulated microbial activity.

Replacement of Corn cobs treated with fungus and yeast up to level of $30 \%\left(\mathrm{R}_{4}\right)$ maintained the significantly highest value of ruminal TVFA's before feeding followed by $R_{3}$ and $R_{2}$, the lowest values recorded for the control group. These results agree with those obtained by Henics (1987) who found that the level of ruminal TVFA's reached to maximum at $3 \mathrm{hrs}$. after feeding for lambs fed ad-libitum. These results of biological treatments might be related to the more utilization of the dietary energy and positive fermentation in the rumen. On the contrary, the lowest $\mathrm{pH}$ values were recorded after $3 \mathrm{hrs}$ of feeding for the different treatments. 
Table (5): Effect of the experimental rations and sampling time on $\mathrm{pH}$, ammonia $\left(\mathrm{NH}_{3}-\mathrm{N}\right)$ and total volatile fatty acid (TVFA's) concentrations in the rumen of lambs.

\begin{tabular}{|c|c|c|c|c|c|}
\hline \multirow[t]{2}{*}{ Item } & \multirow{2}{*}{$\begin{array}{c}\text { Time of } \\
\text { sampling } \\
\text { (hrs) }\end{array}$} & \multicolumn{4}{|c|}{ Experimental rations } \\
\hline & & $\mathrm{R}_{1}$ & $\mathrm{R}_{2}$ & $\mathrm{R}_{3}$ & $\mathrm{R}_{4}$ \\
\hline \multirow{4}{*}{\multicolumn{2}{|c|}{$\mathrm{pH}$}} & & & & \\
\hline & & $7.03 \pm 0.120$ & $7.07 \pm 0.182$ & $6.98 \pm 0.129$ & $7.31 \pm 0.267$ \\
\hline & & $6.66^{\mathrm{ab}} \pm 0.114$ & $6.52^{\mathrm{b}} \pm 0.157$ & $6.96^{\mathrm{ab}} \pm 0.234$ & $7.16^{\mathrm{a}} \pm 0.166$ \\
\hline & & $7.18 \pm 0.235$ & $7.33 \pm 0.287$ & $7.22 \pm 0.192$ & $7.33 \pm 0.133$ \\
\hline \multicolumn{6}{|c|}{$\mathrm{NH}_{3}-\mathrm{N}, \mathrm{mg} / 100 \mathrm{ml}$} \\
\hline & & $12.14 \pm 0.763$ & $12.05 \pm 1.133$ & $12.88 \pm 1.228$ & $15.21 \pm 0.87$ \\
\hline & 3 & $16.95^{\mathrm{b}} \pm 0.437$ & $23.44^{\mathrm{a}} \pm 1.231$ & $24.11^{\mathrm{a}} \pm 2.467$ & $25.03^{\mathrm{a}} \pm 0.431$ \\
\hline & 6 & $12.99^{c} \pm 0.109$ & $17.36^{\mathrm{b}} \pm 1.584$ & $19.4^{\mathrm{ab}} \pm 1.224$ & $21.92^{\mathrm{a}} \pm 1.167$ \\
\hline \multicolumn{6}{|c|}{ TVFA's, meq/100ml } \\
\hline & 0 & $8.22^{\mathrm{b}} \pm 0.725 \mid$ & $9.32^{\mathrm{ab}} \pm 0.451$ & $\left|9.53^{\mathrm{ab}} \pm 0.364\right|$ & $10.32^{\mathrm{a}} \pm 0.133$ \\
\hline & & $10.23^{\mathrm{b}} \pm 0.546$ & $12.95^{\mathrm{a}} \pm 0.419$ & $13.59^{\mathrm{a}} \pm 0.474$ & $13.76^{a} \pm 0.385$ \\
\hline & 6 & $8.83 \pm 0.378$ & $9.37 \pm 0.145$ & $9.00 \pm 0.458$ & $9.24 \pm 0.183$ \\
\hline
\end{tabular}

- $a, b$ and c Means in the same row with different superscripts are significantly $(\mathrm{P}<0.05)$ different.

- Each value is a mean of 3 samples from 3 animals.

\section{Effect of feeding biological treated corn cobs on blood parameters:}

Data of hemato-biochemical parameters are presented in Table 6. The obtained results indicated that the biological treated corn cobs at 30\% replacement $\left(R_{4}\right)$ had a significant higher effect on lymphocytes than that other treatments. However, the different experimental rations had nonsignificant effect on $\mathrm{Hb}$, RBc's and WBc's parameters. Such effects varied from being negative to positive. Serum total protein and albumin 
were increased significantly $(\mathrm{P}<0.05)$ with fungal and yeast treatment $\left(\mathrm{R}_{4}\right)$ compared with the other treatments, however, serum globulin and $A / G$ ratio were not affected by the treatments (Table 6). Serum total protein reflects the nutritional status of the animal and it has a positive correlation with dietary protein (Kumar et al., 1980). These results are parallel with values of organic matter and crude protein digestibility. It is of interest to note that levels of rumen liquor ammonia-nitrogen show the same trend of serum total protein.

The results of total protein and albumin are in a good agreement with the findings of El-Ashry et al. (1997) and Khorshed (2000) who found that biological treatments increased serum total protein (in sheep). Also, the results of yeast treatment are in accordance with those obtained by Abo El-Nor and Kholif (1998) and Kholif et al. (2000). However, Piva et al. (1993) found that levels of blood plasma total protein were not affected adversely by added dietary yeast culture.

The results of globulin are in the line of those obtained by ElAshry et al. (1997) and Khorshed (2000) (with fungal culture treatments) and Piva et al. (1993). Abo El-Nor and Kholif (1998) and Kholif et al. (2000) (with yeast treatments supplementation).

Values of serum urea were affected by the treatments (Table 6). The results are in agreement with those obtained by El-Ashry et al. (1997) and Khorshed (2000).who reported a significant increase in serum urea nitrogen concentration with fungal treatments. On the other hand, Abo El-Nor and Kholif (1998) and Kholif et al. (2000) reported significant increase in serum urea nitrogen concentration with yeast culture supplement.

Values of serum creatinine were improved by the treatment. Generally, serum creatinine level is a useful indicator of glomerular filtration in the kidney. Regarding to the results of serum urea nitrogen and serum creatinine concentrations, it is clear that the tested animals 
were not in a catabolism situation and kidney function was improved by the biological treatments. Consequently, the animals were in a good nutritional conditions.

Serum glucose concentrations were not affected by the treatments, however, triglycerides improved by the biological treatment compared with the control ration. The slighte increase of serum glucose with biological treatments may be due to higher $\mathrm{OM}$ and $\mathrm{CF}$ digestibilities and higher TVFA's content in rumen of animals given the treated rations.

These results are closed with the findings of Piva et al. (1993), they reported that plasma glucose were not affected adversely by the added dietary yeast culture. However, Abo El-Nor and Kholif (1998), Sharma et al.(1998) and Kholif et al. (2000) stated that serum glucose content increased significantly with yeast culture supplementation to buffaloes or cows rations.

Serum cholesterol recorded a significantly decreased with biological treatment compared with the control ration. However, Piva et al.(1993). found that plasma cholesterol was not affected by the added dietary yeast culture to cows ration. While, Kholif et al. (2000) reported a significant increase $(\mathrm{P}<0.05)$ of serum cholesterol with yeast culture (Yea Sacc group) compared with the control.

The activity serum AST and serum ALT were improved by the biological treatment compared to the control ration. The results of biological treatment are in agreement with those of Abo El-Nor and Kholif (1998). While, Kholif et al. (2000) found that serum AST activity recorded insignificant increase $(\mathrm{P}>0.05)$ with dietary yeast culture supplement. The present values of AST and ALT showed normal activity of the animal hepatic tissues and consequently, the biological treatments applied in the present study could be used without any adverse effect on 
the liver function. Consequently the animals were in a good nutritional condition.

Table (6): Blood profile of sheep as affected by the experimental treatments.

\begin{tabular}{|c|c|c|c|c|}
\hline Items & $\mathbf{R}_{1}$ & $\mathbf{R}_{\mathbf{2}}$ & $\mathbf{R}_{3}$ & $\mathbf{R}_{4}$ \\
\hline $\mathrm{Hb}, \mathrm{g} / \mathrm{dl}$ & $\begin{array}{l}10.10 \\
\pm 0.478\end{array}$ & $\begin{array}{l}10.20 \\
\pm 0.478\end{array}$ & $\begin{array}{l}11.33 \\
\pm 0.337\end{array}$ & $\begin{array}{l}11.38 \\
\pm 0.272\end{array}$ \\
\hline RBC's x $10^{6} / \mu 1$ & $\begin{array}{l}8.75 \\
\pm 0.212\end{array}$ & $\begin{array}{l}8.90 \\
\pm 0.287\end{array}$ & $\begin{array}{l}9.34 \\
\pm 0.212\end{array}$ & $\begin{array}{l}10.5 \\
\pm 0.265\end{array}$ \\
\hline WBC's, x $10^{3} / \mu 1$ & $\begin{array}{l}8.33 \\
\pm 0.182\end{array}$ & $\begin{array}{l}7.80 \\
\pm 0.181\end{array}$ & $\begin{array}{l}8.70 \\
\pm 0.112\end{array}$ & $\begin{array}{l}9.3 \\
\pm 0.184\end{array}$ \\
\hline Lymphocytes \% & $\begin{array}{l}35.33 \\
\pm 0.451\end{array}$ & $\begin{array}{l}36.66^{\mathrm{b}} \\
\pm 0.421\end{array}$ & $\begin{array}{l}36.00^{\mathrm{b}} \\
\pm 0.414\end{array}$ & $\begin{array}{l}48.33^{\mathrm{a}} \\
\pm 0.123\end{array}$ \\
\hline Total protein $\mathrm{g} / 100 \mathrm{ml}$ & $\begin{array}{l}5.95^{\mathrm{b}} \\
\pm 1.112\end{array}$ & $\begin{array}{l}6.06^{\mathrm{b}} \\
\pm 1.416\end{array}$ & $\begin{array}{l}5.88^{\mathrm{b}} \\
\pm 1.196\end{array}$ & $\begin{array}{l}6.48^{\mathrm{a}} \\
\pm 1.112\end{array}$ \\
\hline Albumin(A), g/100ml & $\begin{array}{l}3.00^{\mathrm{b}} \\
\pm 2.621\end{array}$ & $\begin{array}{l}3.20^{\mathrm{b}} \\
\pm 1.023\end{array}$ & $\begin{array}{l}3.24^{\mathrm{b}} \\
\pm 2.145\end{array}$ & $\begin{array}{l}3.38^{\mathrm{a}} \\
\pm 2.021\end{array}$ \\
\hline Globulin $(\mathrm{G}), \mathrm{g} / 100 \mathrm{ml}$ & $\begin{array}{l}2.95 \\
\pm 0.123\end{array}$ & $\begin{array}{l}2.86 \\
\pm 0.174\end{array}$ & $\begin{array}{l}2.64 \\
\pm 0.125\end{array}$ & $\begin{array}{l}3.10 \\
\pm 0.123\end{array}$ \\
\hline $\begin{array}{l}\text { Albumin/Globulin } \\
\text { ratio,(A/G) }\end{array}$ & $\begin{array}{l}1.02 \\
\pm 1.512\end{array}$ & $\begin{array}{l}1.12 \\
\pm 1.014\end{array}$ & $\begin{array}{l}1.23 \\
\pm 1.485\end{array}$ & $\begin{array}{l}1.09 \\
\pm 1.511\end{array}$ \\
\hline Urea, $\mathrm{mg} / 100 \mathrm{ml}$ & $\begin{array}{l}47.3^{\mathrm{b}} \\
\pm 0.214\end{array}$ & $\begin{array}{l}46.4^{\mathrm{b}} \\
\pm 0.458\end{array}$ & $\begin{array}{l}53.6^{\mathrm{a}} \\
\pm 0.451\end{array}$ & $\begin{array}{l}56.5^{\mathrm{a}} \\
\pm 0.421\end{array}$ \\
\hline Creatinine, $\mathrm{mg} / 100 \mathrm{ml}$ & $\begin{array}{l}0.59^{\mathrm{a}} \\
\pm 0.101\end{array}$ & $\begin{array}{l}0.45^{\mathrm{b}} \\
\pm 0.121\end{array}$ & $\begin{array}{l}0.49^{\mathrm{b}} \\
\pm 0.133\end{array}$ & $\begin{array}{l}0.38^{\mathrm{c}} \\
\pm 0.118\end{array}$ \\
\hline Glucose, $\mathrm{mg} / 100 \mathrm{ml}$ & $\begin{array}{ll}57.21 \\
\pm 0.412 \\
\end{array}$ & $\begin{array}{l}58.33 \\
\pm 0.458 \\
\end{array}$ & $\begin{array}{l}62.67 \\
\pm 0.214 \\
\end{array}$ & $\begin{array}{l}63.33 \\
\pm 0.421\end{array}$ \\
\hline Triglycrides $\mathrm{mg} / 100 \mathrm{ml}$ & $\begin{array}{l}59.00^{\mathrm{a}} \\
\pm 0.321\end{array}$ & $\begin{array}{l}57.00^{b} \\
\pm 0.214\end{array}$ & $\begin{array}{l}47.00^{\mathrm{c}} \\
\pm 0.123\end{array}$ & $\begin{array}{l}51.00^{\mathrm{c}} \\
\pm 0.412\end{array}$ \\
\hline Cholesterol, mg/100ml & $\begin{array}{l}115.0^{\mathrm{a}} \\
\pm 0.412\end{array}$ & $\begin{array}{l}99.83^{\mathrm{b}} \\
\pm 0.432\end{array}$ & $\begin{array}{l}82.83^{\mathrm{b}} \\
\pm 0.403\end{array}$ & $\begin{array}{l}81.66^{\mathrm{c}} \\
\pm 0.411\end{array}$ \\
\hline $\mathrm{ALT}, \mathrm{u} / \mathrm{l}$ & $\begin{array}{l}23.00^{\mathrm{a}} \\
\pm 0.107\end{array}$ & $\begin{array}{l}18.67^{\mathrm{b}} \\
\pm 0.133\end{array}$ & $\begin{array}{l}18.33^{\mathrm{b}} \\
\pm 0.121\end{array}$ & $\begin{array}{l}15.48^{\mathrm{c}} \\
\pm 0.133\end{array}$ \\
\hline AST, u/l & $\begin{array}{l}38.00^{\mathrm{a}} \\
\pm 0.113 \\
\end{array}$ & $\begin{array}{l}37.20^{\mathrm{a}} \\
\pm 0.133 \\
\end{array}$ & $\begin{array}{l}30.3^{\mathrm{b}} \\
\pm 0.103 \\
\end{array}$ & $\begin{array}{l}27.6^{\mathrm{c}} \\
\pm 0.146 \\
\end{array}$ \\
\hline
\end{tabular}

a, $b$ and c: Means of the same row with different superscript are significantly different $(\mathbf{P}<\mathbf{0 . 0 5})$.

\section{Economical study:}

In this study (Table 7) results of the economical study showed that the feed cost $/ \mathrm{kg}$ weight gain (L.E) of the control treatment $\left(\mathrm{R}_{1}\right)$ showed 
the highest values while the lowest cost was for $R_{4}$. The best relative economical efficiency was detected with $\left(\mathrm{R}_{4}\right)$. These results are in agreement with the results obtained by Deraz (1996) who indicated that the chemical and chemofungal treatment decreased the cost of feed used to produce kg live body weight gain.Abd El-Aziz (2002) observed that replacing $40 \%$ of the FM by biologically treated rice straw reduced the cost of feeding by $28.8 \%$. Allam et al. (2006) reported that the treated sugar beet pulp biologically to replace $0,60,75$ or $100 \%$ of corn grain for growing lamb (groups $R_{1}, R_{2}, R_{3}$ and $R_{4}$, respectively) showed the least feed cost $/ \mathrm{kg}$ gain for lamb treatment $\left(\mathrm{R}_{4}\right)$.

Table (7): Effect of incorporation of treated corn cobs in ration on economical efficiency of growing lambs.

\begin{tabular}{|l|c|c|c|c|}
\hline \multirow{2}{*}{\multicolumn{1}{c|}{ Item }} & \multicolumn{4}{c|}{ Treatment } \\
\cline { 2 - 5 } & $\mathrm{R}_{1}$ & $\mathrm{R}_{2}$ & $\mathrm{R}_{3}$ & $\mathrm{R}_{4}$ \\
\hline DMI (g/h/d) & 1627 & 1645 & 1644 & 1666 \\
\hline Feed mixture (DMI), g & 1057 & 1065 & 1064 & 1066 \\
\hline Roughage (DMI), g & 570 & 580 & 580 & 600 \\
Av. daily gain (kg/h/d) & 0.240 & 0.242 & 0.266 & 0.275 \\
Av. feed cost (h/d/LE) & 1.245 & 1.214 & 1.170 & 1.136 \\
Av. revenue of daily gain (LE) & 4.080 & 4.114 & 4.522 & 4.675 \\
Net feed revenue (LE) & 2.835 & 2.900 & 3.352 & 3.539 \\
Economic feed efficiency (\%) & 227.71 & 238.88 & 286.49 & 311.53 \\
Relative economic efficiency (\%) & 100 & 104.90 & 125.81 & 136.80 \\
\hline
\end{tabular}

Price of ton $C F M R_{1}=1017 \mathrm{LE} \quad R_{2}=977 \mathrm{LE} \quad R_{3}=937 \mathrm{LE} \quad R_{4}=897 \mathrm{LE}$ (including 100LE/ton as cost for biological (treatment + manufacture) price of 1 ton clover hay $=700 \mathrm{LE}$. Price of 1 ton groundnut vines hay $=300$ LE. Price of 1 ton corn cobs $=200$ LE. Market price of $1 \mathrm{Kg}$ live body weight in (2006) $=17$. L.E.

Results of the present study indicated that, replacement of $10 \%$ of corn cobs treated with (fungal+ yeast) instead of Berseem hay in lambs diets did not significantly adverse growth and feed utilization parameters and did not improve economic feed efficiency. However, replacement of $20 \%$ and $30 \%$ of treated corn cobs instead of Berseem hay in sheep diets were significantly affected growth and feed utilization parameter and reduced feed cost $/ \mathrm{kg}$ diet. The higher replacing levels with instead of Berseem hay significantly increased growth and feed utilization parameters and also reduced feed cost $/ \mathrm{kg}$ diet and feed cost/kg weight gain.

\section{CONCLUSION}

From the results obtained in the present study, it could conclude the possibility of replacing $30 \%$ of Berseem hay by treated corn cobs with (fungus+ yeast) in sheep diets without adverse effect on growth or feed utilization parameters. This replacement reduced feed costs $/ \mathrm{kg}$ diet and feed costs/kg weight gain and improved economic efficiency for feeding sheep. 


\section{References}

Abd El-Aziz, M.Y. (2002). Nutritional studies on biological treatment of agricultural by-product on ruminants. M.Sc. thesis, Faculty of Agric; Zagazig University, Egypt.

Abd El-Kareem, F.A. (1990). Improvement utilization of roughage by goats. Ph.D. Thesis, Fac. of Agric. Cairo Univ.

Abo El-Nor, S.A.H. and A.M. Kholif (1998). Effect of supplementation of live yeast culture in the diet on the productive performance of lactating buffaloes. Milchwissenschaft, 53: 663-666.

Allam S.M.; T.M. Al-Bedawi; Hanaa; H. El-Amany and Shereen, H. Mohamed (2006). Improving sugar beet pulp through biological treatment and its use in sheep ration. Egyptian J. Nutrition and Feeds. 9(2): 235-247.

A.O.A.C. (1995). Methods of analysis. Vol. 1: Agricultural Chemicals, contaminates, Drugs. $16^{\text {th }}$ ed. Washington. D.C., USA.

Armstrong, W.D. and C.W. Carr (1964). Physiological Chemistry Laboratory Directions, $3^{\text {rd }}$ cd. P. 75 Burges Publishing Co. Minneapolis. Minnewota.

Beauychemin, K.A.; W.Z. Yang and L.M. Rode (1999). Effect of grain source and enzyme additive on site and extent of nutrient digestion in dairy cows.J. Dairy Sci., 82: 378-390.

Bouattour, M.A. (2004). Effect of using fibrolytic enzymes and soyabean oil in dairy ewes feeding. M.Sc. thesis. CIHEAM. Instituto Agromediterr Jneo de Zaragoza Spain.

Dawson, K.A. (1992). Current and future role of yeast cultures in animal production: A review of research over the last six years. In: Supplement to the Proceedings of Alltech's $8^{\text {th }}$ Annual Symposium, $1: 23$.

Deraz, T.A. (1996). The production of microbial protein from some agricultural wastes and its utilization in ruminant. Ph.D. Thesis, Faculty of Agric,Ain-Shams University, Cairo, Egypt.

Doumas, B.; W. Wabson and H. Biggs (1971). Albumin standards and measurement of serum with bromocresol green. Clin. Chem. Acta, 31: 87.

Duncan,D.B.(1955).Multiple range and multiple F test.Biometrics 11:1-42 
El-Ashry, M.A.; M.F. Ahmed; S.A. El-Saadany; M.E.S. Youssef; L.V. Gomaa and T.A.A. Deraz (1997). Effect of mechanical vs. mechano-chemical or mechano-biological treatments of cropresidues on their use in ruminant rations: Digestibility, nitrogen balance and some blood and rumen liquor parameters of sheep. Egyptian J. Nutrition and Feeds 1: (Special Issue): 173-186.

El-Ashry, M.A.; A.M. Kholif; M. Fadel; H.A. El-Alamy; H. M. El-Sayed and S.M. Kholif (2003). Effect of biological treatments on chemical composition and in vitro and in vivo digestibiliteis of poor quality roughages Egyptian. J. Nutr. \& Feeds, 6: 113-126.

El-Kady, R.I.; I.M. Awadalla; M.I. Mohamed; M. Fadel and H.H. Abd El-Rahman (2006). Effect of exogenous enzymes on the growth performance and digestibility of growing buffalo calves. International J. of Agriculture and Biology, 8; 354-359.

Fadel, M. (2001). High level xylanase production from sorghum flour by a newly isolate of Trichoderma horzianum cultivated under solid state fermentation. Annals of Microbiology, 51: 61.

Flores, C. (2004). Use of fibrolytic enzymes in dairy goats in vitro evaluation of activity and fermentative characteristics. Ph. D. Thesis. Universidad Autnoma de Barcelona, Spain.

Gonzilez, E. (2004). Improvement of sheep production by using fibrolytic enzymes in dairy ewes and malate in fattening lambs. Ph.D. Thesis. Universidad Autnoma de Barcelona Spain.

Gutierrez, C.; G.D. Mendoza; J.M. Pinos-Rodriguez; R. Ricalde; E. Aramada and L.A. Miranda (2005). Effect of storage time and processing temperature of grains with added amylolytic enzymes on in situ ruminal starch digestion. J. of Applied Anim. Research, 27(1): 39-44.

Haddad, S.G. and S.N. Goussous (2005). Effect of yeast culture supplementation on nutrient intake, digestibility and growth performance of Awassi lambs. Animal Feed Science and Technology, 118(3/4): 343-348.

Henics, Z. (1987). Wheat straw upgraded by P. ostearus. World Review of Animal Prod., 111 No. (4): Egyptian J. Nutrition and Feeds, 112-119.

Husdan, H. (1968). Chemical determination of creatinine with deproteinization. Clin. Chem., 14: 222. 
Kholif, A.A.; H.A. El-Alamy; M.A. El-Ashry; H.M. El-Sayed and T.A. Ali (2000). Effect of supplementation of different types of live yeast cultures in the diet on the productive performance of lactating buffaloes. Egyptian J. Dairy Sci., 28: 281-295.

Khorshed, M.M.A. (2000). Different treatment for improving nutritional quality of some crop residues used in ruminant nutrition. Ph.D. Thesis, Fac. of Agric., Ain Shams Univ; Egypt.

Kumar, N.U.; B. Singh and D.N. Verma (1980). Effect of different levels of dietary protein and energy on growth of male buffalo calves. Ind. J. Anim. Sci., 51: 513.

Lewis, G. E; W.K. Sanchez; C.W. Hunt; M.A. Guy; G.T. Pritchard; B.I. Swanron and R.J.Treacher (1999). Effect of direct feed fibrolytic enzymes on the lactational performance of dairy cows. J. Dairy. Sci., 82: 611-617.

Mc Allister, T.A.; S.P. Oosting; J.D. Popp; Z. Mir; L.J. Yanke; A.N. Histrov; R.J. Treacher and K.J. Cheng (1999). Effect of exogenous enzyme on digestibility of barley silage and growth performance of feedlot cattle. Can. J. Anim. Sci., 79: 353-359.

Patton, C.J. and S.R. Crouch (1977). Spectrophotometric and kinetics investigation of the berthelot reaction for the determination of ammonia. Anal. Chem., 49: 464-469.

Piva, G.; S. Belladonna; G. Fusconi and F. Sicbaldi (1993). Effects of yeast on dairy cow performance, ruminal fermentation, blood components and milk manufacturing properties. J. Dairy Sci., 76: 9, 2717-2722.

Plata-Perez, F.X.; R. Ricaldo; L.M. Melgoza; A. Lara and G. Mendoza (2004). Effects of monensin and yeast culture (Saccharomyces cervisiae) treatment on sheep performance. Revista-scientifica, Faculted-de-Ciencias-veterinarias-Universidad-del-Zulia., 14(6): 522525.

Postma, T. and J.A. Stroes (1968). Lipids screening in clinical chemistry. Clinica Chemica Acta, 22: 569.

Rai, S.N. and V.D. Mudgal (1984). Utilization of poor quality roughages. 2. enzymic treatment of wheat straw. Asian. J. Dairy Res., 3(4): 193-200.

Raltiff, C.R. and F. Hall (1973). Laboratory Manual of Clinical Biochemistry. Scott and Memorial Hospital Publication Office, Temple, TX. 
Reitman, S. and S. Frankel (1957). Colorimetric method for the determination of serum glutamic-oxaloacetic and glutamicpyruvate transminase. An. J. Clin. Path., 28: 56.

Rode L.M.; W.Z. Yang and K.A. Beauchemin (1999). Fibrolytic enzyme supplements for dairy cows in early lactation. J. Dairy Sci., 82: 2121-2126.

SAS (1989). Statistical analysis system. SAS User's Guide Statistics. SAS Institute Inc. Editors, Cary, NC.

Sharma R.; O.P. Nagia; M. Gupta and R. Sharma (1998). Effect of yeast culture (Saccharomyces cerevisiae) plus growth medium supplementation on rumen fermentation in buffalo calves fed high roughage diet. International J. of Anim. Sci., 13: 2, 121-126.

Shoukry, M.M.;F.A. Hamissa; Sawsan, M.Ahmed; A.H. EL-Refai; H.M. Ali and Z.M.Z Abdel- Motagally(1985). Nutritive improvement of some low quality roughages for ruminants.I. Effect of different microbial and chemical treatments on the quality of sugar cane bagasse. Egypt. J. Anim. Prod., 25:329-342.

Siest G.; J. Henny and F. schiele (1981). Inter pretation des examens de laboratoire. Kargered., 206.61, p. 37.

Tawila, M.A. (1991). Studies on the possible methods for improving utilization of low quality roughages for ruminants. Ph.D. Thesis, Ain Shams Univ.

Titi, H.H. (2004). Response of Awassi Lambs to enzymatic treatment fed two different forages. 1. Digestibility and growth performance. Dirasat. Agricultural Sciences 31(3): 302-310.

Ward M.H and S.E. Perry (1982). Enzymatic conversion of corn cobs to glucose with Trichoderma viride fungus and the effect on nutritional value of the corn cobs. J. of Anim. Sci., 54: 609.

Warner, A.C.J. (1964). Production of volatile fatty acids in the rumen. Methods of measurements. Nutr. Abst \& Rev., 34: 339.

Williams, P.E.and C.J. Newbold (1990). Rumen proboscis: The effect of novel microorganisms on rumen fermentation and ruminal production. In. W. Hersign and D.J. Cole (Eds). Recent Advances in Animal Nutrition p. 211-223, Butter Worth, London.

Yang W.Z.; K.A. Beauchemin and L.M. Rode (1999). Effects of enzyme feed additive on extent of digestion and milk production of lactating dairy cows. J. Dairy Sci., 82: 391-403.

Zewil, M.G.M. (2005). Evaluation of some treatments for rice straw. M.Sc. Thesis, Faculty of Agric., Al-Azhar University, Egypt. 


\section{تحسين الأستفادة من قوالح الأذرة في علائق الأغنام باستخدام المعاملات البيولوجية

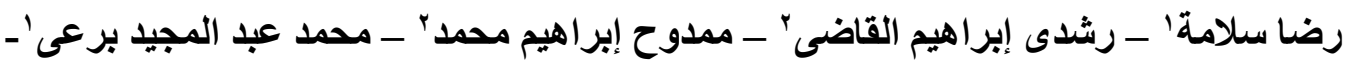

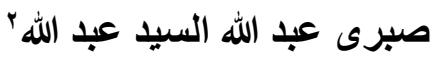

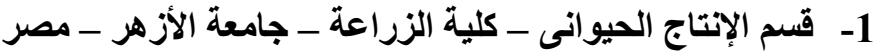

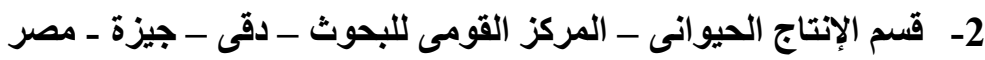

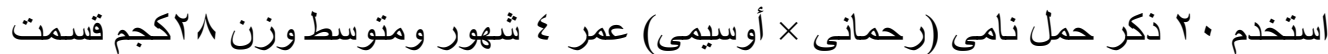

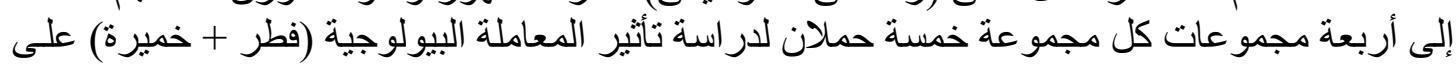

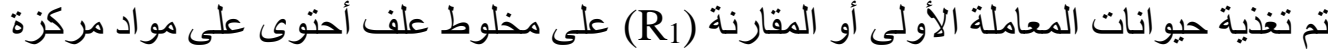

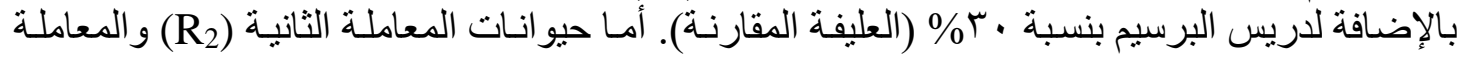

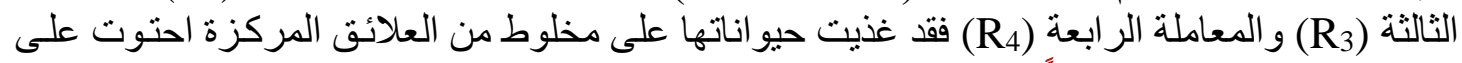

قو الح الذرة المعاملة بيولوجياً بفطر Trichoderma reesei F-418 +خميرة

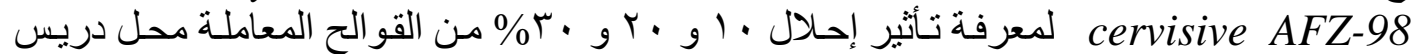

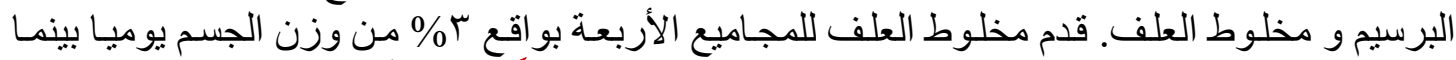

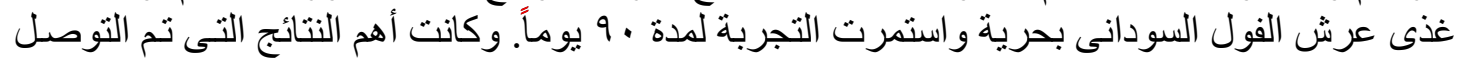

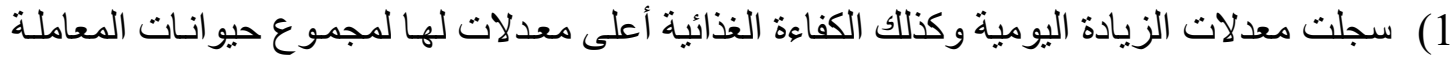

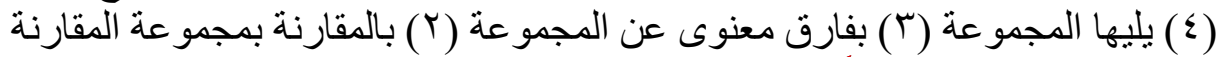

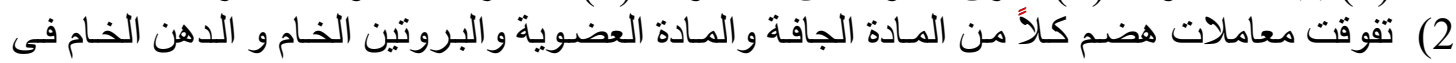

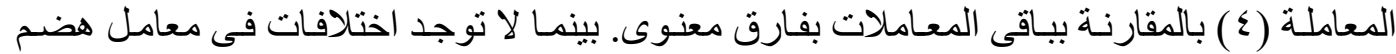

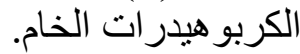

3) سجلت الأحماض الدهنية الطيارة الكلية وكذلك أمونيا نبتروجين سائل الكرش أعلى معدلات لها عند

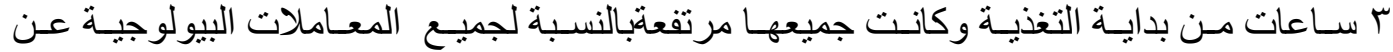
المجمو عة المقارنة.

4) تحسنت صورة الدم وكذلك وظة الكائف الكبد و الكلى للمعاملات المختلفة مقارنة بمجمو عة المقارنة بدون

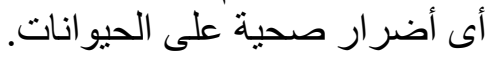

5) أوضحت النتائج أن أقل تكلفة للغذاء لانتاج اكجم وزن مكتسب كانت للمجمو عة الر ابعة.

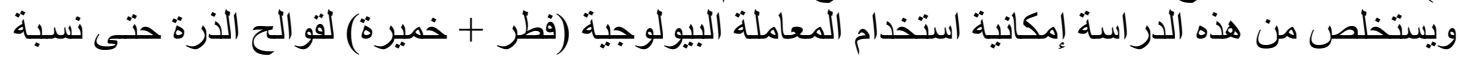

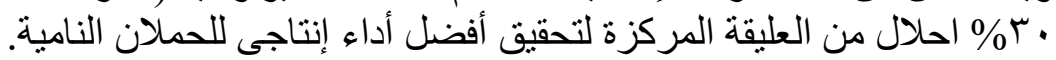

